\title{
Genetic Relationships among Eubacterium Species
}

\author{
FUTOSHI NAKAZAWA* AND ETSURO HOSHINO \\ Department of Oral Microbiology, School of Dentistry, \\ Niigata University, Niigata 951, Japan
}

\begin{abstract}
The genetic relationships among Eubacterium species were assessed by using DNAs from American Type Culture Collection type strains of 10 species and two subspecies of the genus Eubacterium, i.e., Eubacterium aerofaciens, E. alactolyticum, E. brachy, E. lentum, E. limosum, E. nodatum, E. rectale, E. saburreum, E. timidum, $E$. yurii subsp. yurii, and $E$. yurii subsp. margaretiae. The DNA base compositions (determined by highperformance liquid chromatography) of these species varied widely, from 38 to $62 \mathrm{~mol} \% \mathrm{G}+\mathrm{C}$. Seven Eubacterium species showed significant differences (nearly $10 \%$ ) in $G+C$ content compared with $E$. limosum, the type species of the genus. DNA-DNA hybridization (by the membrane filter method) showed that two subspecies, $E$. yurii subsp. yurii and $E$. yurii subsp. margaretiae, and two strains of $E$. timidum exhibited high levels of DNA relatedness. However, the DNA reassociations among the 10 Eubacterium species studied were 1 to $16 \%$. None of the species examined shared a high level of DNA reassociation with the type species of the genus Eubacterium. The protein profile patterns (determined by sodium dodecyl sulfate-polyacrylamide gel electrophoresis) of whole bacterial cells from these Eubacterium species were distinct, and no major peptide bands were shared among the 10 Eubacterium species. Therefore, the Eubacterium species we tested must be considered genetically distinct from each other.
\end{abstract}

Numerous bacterial strains of non-spore-forming, grampositive, obligately anaerobic rods belonging to the genus Eubacterium have been isolated from human oral cavities (7), including those from dental plaque $(3,6,16,30)$, periodontal lesions $(18,20,29,31)$, infected dental pulp $(6,27)$, and carious dentine $(1,2,5)$. Recognized among them in the past decade are many new species of Eubacterium (e.g., Eubacterium brachy, E. nodatum, E. timidum, E. yurii, and E. saphenum). Some of these species are associated with moderate and severe periodontitis and are less frequent in the supragingival sites or subgingival sites of healthy persons $(13,19,32,34,35)$.

The genus Eubacterium includes more than 40 species exhibiting diverse morphologies and shows biochemical, physiological, and serological heterogeneity $(4,11,21,22,25,28$, 33). We have found that the oral Eubacterium species are clearly distinguished by serological reactions (24), and this immunological heterogeneity suggests that they are a genetically heterogeneous group of microorganisms. There is no comprehensive study of relationships among Eubacterium species by DNA reassociation, although the limited data on the $\mathrm{G}+\mathrm{C}$ content of DNA suggests heterogeneity and the need for research.

Ten species and two subspecies of the genus Eubacterium, including the type species and type strains, were selected for the present study. Variations in $\mathrm{G}+\mathrm{C}$ content and DNA-DNA hybridization among these species were determined to assess the extent of heterogeneity among these Eubacterium species.

\section{MATERIALS AND METHODS}

Bacterial strains and culture conditions. E. aerofaciens ATCC $25986^{\mathrm{T}}$ ( $\mathrm{T}=$ type strain), E. alactolyticum ATCC $23263^{\mathrm{T}}$, E. brachy ATCC $33089^{\mathrm{T}}$, E. lentum ATCC $25559^{\mathrm{T}}, E$. limosum ATCC $8486^{\mathrm{T}}$, E. nodatum ATCC $33099^{\mathrm{T}}$, E. rectale ATCC $33656^{\mathrm{T}}$, E. saburreum ATCC $33271^{\mathrm{T}}$, E. timidum ATCC 33092, E. timidum ATCC $33093^{\mathrm{T}}$, E. yurii subsp. yurii ATCC

* Corresponding author. Mailing address: Department of Oral Microbiology, School of Dentistry, Niigata University, Gakko-cho-dori 2, Niigata 951, Japan. Phone: 025 (225) 0513. Fax: 025 (225) 0513.
$43714^{\mathrm{T}}$, and E. yurii subsp. margaretiae ATCC $43715^{\mathrm{T}}$ were used as representatives of these species. Actinomyces viscosus ATCC 19246 and Prevotella nigrescens NCTC 9336 were also used for comparisons of DNA-DNA homology. All bacterial strains were cultured in brain heart infusion broth (Difco Laboratories, Detroit, Mich.) supplemented with bovine serum, hemin, and vitamin $\mathrm{K}_{1}$. Cultures were incubated at $37^{\circ} \mathrm{C}$ for 3 days in an anaerobic chamber (Hirasawa Works, Tokyo, Japan) containing an atmosphere of $80 \% \mathrm{~N}_{2}, 10 \% \mathrm{H}_{2}$, and $10 \% \mathrm{CO}_{2}$. The bacterial cells were harvested by centrifugation at $10,000 \times g$ for $20 \mathrm{~min}$ at $4^{\circ} \mathrm{C}$, washed with $10 \mathrm{mM}$ sodium phosphate-buffered saline ( $\mathrm{pH} \mathrm{7.2)}$, and stored at $-20^{\circ} \mathrm{C}$ until used for DNA extraction.

Cell lysis and DNA isolation. Bacterial cells (wet weight, $1 \mathrm{~g}$ ) were resuspended in $5 \mathrm{ml}$ of saline-EDTA buffer $(0.15 \mathrm{M}$ $\mathrm{NaCl}, 0.1 \mathrm{M}$ EDTA, pH 8.0), and frozen. The suspensions were subjected to ultrasonication for $10 \mathrm{~min}$ after being frozen and thawed three times, and then they were treated with $20 \mathrm{mg}$ of lysozyme $\left(50,000 \mathrm{U} / \mathrm{mg}\right.$ of protein) at $37^{\circ} \mathrm{C}$ for $30 \mathrm{~min}$. After 15 $\mathrm{ml}$ of $0.1 \mathrm{M}$ Tris buffer ( $\mathrm{pH} 9.0$ ) containing $1 \%$ (wt/vol) sodium dodecyl sulfate (SDS) was added, incubation at $60^{\circ} \mathrm{C}$ was continued until the solution became clear. DNA was isolated from the cell lysates by the method of Marmur (15) with slight modifications. Briefly, the cell lysate was thoroughly extracted with 0.5 volume of water-saturated liquid phenol with shaking for $30 \mathrm{~min}$ at room temperature. The phases were separated by centrifugation, and the aqueous phase was saved. DNA was then precipitated in an ice bath by addition of 2 volumes of $95 \%$ ethanol. The precipitate was collected by centrifugation at $4^{\circ} \mathrm{C}$ and washed with 70,80 , and $90 \%$ ethanol, in that order. After drying, the precipitate was dissolved in $0.1 \times \mathrm{SSC}(1 \times$ SSC is $0.15 \mathrm{M} \mathrm{NaCl}$ plus $15 \mathrm{mM}$ sodium citrate, $\mathrm{pH} 7.0$ ) at $4^{\circ} \mathrm{C}$. RNase A (Boehringer $\mathrm{GmbH}$, Mannheim, Germany; previously heated at $80^{\circ} \mathrm{C}$ for $10 \mathrm{~min}$ to deactivate DNase) was then added to a final concentration of $50 \mu \mathrm{g} / \mathrm{ml}$, and the solution was incubated for $1 \mathrm{~h}$ at $37^{\circ} \mathrm{C}$. After $50 \mu \mathrm{l}$ of proteinase $\mathrm{K}(10$ $\mathrm{mg} / \mathrm{ml}$; Boehringer) was added, the DNA preparation was incubated at $37^{\circ} \mathrm{C}$ for $1 \mathrm{~h}$. After that, extraction with equal volumes of a mixture of phenol and chloroform (1:1; previously saturated with water) and ethanol precipitation were repeated 
TABLE 1. DNA base composition and levels of DNA-DNA homology among Eubacterium species

\begin{tabular}{|c|c|c|c|c|c|c|c|c|c|c|c|c|c|c|c|}
\hline \multirow[b]{2}{*}{$\begin{array}{l}\text { Bacterial source of } \\
\text { unlabeled DNA }\end{array}$} & \multirow[b]{2}{*}{$\begin{array}{l}\mathrm{G}+\mathrm{C}^{a} \\
\text { content } \\
(\mathrm{mol} \%)\end{array}$} & \multicolumn{14}{|c|}{ \% Homology with labeled bacterial DNA ${ }^{b}$ from strain: } \\
\hline & &  & $\begin{array}{l}\tilde{8} \\
\tilde{8} \\
\tilde{\sigma}\end{array}$ & $\begin{array}{l}5 \\
\stackrel{0}{\circ} \\
\text { ल }\end{array}$ & $\begin{array}{l}\text { 氙 } \\
\text { 气ู }\end{array}$ & $\begin{array}{l}\bar{\phi} \\
\dot{\infty} \\
\infty\end{array}$ & 产 & to & $\overrightarrow{\mathrm{N}}$ & 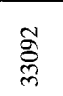 & î̀ &  & $\underset{⿱ 乛}{\stackrel{9}{7}}$ & 号 & $\stackrel{心}{\tilde{\sigma}}$ \\
\hline E. aerofaciens ATCC $25986^{\mathrm{T}}$ & 51 & 100 & 10 & 2 & 3 & 3 & 2 & 2 & 2 & 4 & 2 & 3 & 2 & 2 & 2 \\
\hline E. alactolyticum ATCC $23263^{\mathrm{T}}$ & 61 & & 100 & 2 & 8 & 8 & 8 & 7 & 1 & 8 & 5 & 1 & 4 & 3 & 2 \\
\hline E. brachy ATCC $33089^{\mathrm{T}}$ & 39 & & & 100 & 1 & 2 & 6 & 3 & 16 & 12 & 9 & 6 & 6 & 5 & 1 \\
\hline E. lentum ATCC $25559^{\mathrm{T}}$ & 62 & & & & 100 & 6 & 1 & 1 & 1 & 8 & 4 & 3 & 12 & 5 & 4 \\
\hline E. limosum ATCC $8486^{\mathrm{T}}$ & $50(47)^{c}$ & & & & & 100 & 4 & 4 & 5 & 4 & 5 & 3 & 2 & 3 & 3 \\
\hline E. nodatum ATCC $33099^{\mathrm{T}}$ & $41(36-38)$ & & & & & & 100 & 3 & 7 & 6 & 8 & 5 & 3 & 4 & 1 \\
\hline E. rectale ATCC $33656^{\mathrm{T}}$ & $38(30)$ & & & & & & & 100 & 19 & 2 & 4 & 3 & 2 & 1 & 1 \\
\hline E. saburreum ATCC $33271^{\mathrm{T}}$ & $41(33)$ & & & & & & & & 100 & 4 & 4 & 5 & 2 & 4 & 1 \\
\hline E. timidum ATCC 33092 & 50 & & & & & & & & & 100 & 91 & 4 & 4 & 3 & 1 \\
\hline E. timidum ATCC $33093^{\mathrm{T}}$ & 50 & & & & & & & & & & 100 & 4 & 4 & 3 & 1 \\
\hline E. yurii subsp. yurii ATCC $43714^{\mathrm{T}}$ & $40(32)$ & & & & & & & & & & & 100 & 60 & 3 & 1 \\
\hline E. yurii subsp. margaretia ATCC $43715^{\mathrm{T}}$ & $40(32)$ & & & & & & & & & & & & 100 & 3 & 1 \\
\hline Actinomyces viscosus ATCC $19246^{d}$ & $66(59-69)$ & & & & & & & & & & & & & 100 & 1 \\
\hline Prevotela nigrescens NCTC $9336^{d}$ & $49(41-44)$ & & & & & & & & & & & & & & 100 \\
\hline
\end{tabular}

${ }^{a} \mathrm{G}+\mathrm{C}$ content was measured by HPLC.

${ }^{b}$ All values were normalized to $100 \%$ for the homologous strain.

${ }^{c}$ The data in parentheses are from reference 14 or 21 and were obtained by the thermal melting method.

${ }^{d}$ This bacterial strain was used for comparison.

to achieve the desired level of purity. The DNA concentrations of these preparations were determined spectrophotometrically by determining the $A_{260}$. The purity of each DNA preparation was assessed by measuring the UV $A_{260}$ to $A_{280}$ ratio.

G $+\mathbf{C}$ content of DNA. The $\mathrm{G}+\mathrm{C}$ content of DNA was estimated by high-performance liquid chromatography (HPLC) (10). Each DNA preparation was dissolved in distilled water (1 $\mathrm{mg} / \mathrm{ml}$ ), and then the solution was heated at $100^{\circ} \mathrm{C}$ for $5 \mathrm{~min}$. After rapid cooling in an ice bath, $10 \mu$ lof the denatured DNA solution was mixed with $10 \mu \mathrm{l}$ of a nuclease P1 (Yamasa Shoyu Co., Chiba, Japan) solution ( $2 \mathrm{U} / \mathrm{ml}$ of $40 \mathrm{mM}$ sodium acetate buffer containing $0.2 \mathrm{mM} \mathrm{ZnCl}_{2}$ ) and the mixture was incubated at $50^{\circ} \mathrm{C}$ for $1 \mathrm{~h}$. The hydrolysate and a standard solution containing equal molar concentrations of four deoxyribonucleotide monophosphates (dAMP, dCMP, dGMP, and dTMP) were subjected separately to HPLC (Hitachi L-6200) with a 3013-N column ( 4 by $150 \mathrm{~mm}$ ). The column was eluted with a mobile phase containing $30 \mathrm{mM} \mathrm{KCl}, 10 \mathrm{mM} \mathrm{KH}_{2} \mathrm{PO}_{4}$, and $10 \% \mathrm{CH}_{3} \mathrm{CN}$ (pH 3.5). The deoxyribonucleotide monophosphates were detected with a Hitachi L-4200 apparatus at 267 nm.

DNA-DNA hybridization. The extent of DNA-DNA reassociation was determined by the membrane filter method described by Meyer and Schleifer (17). Briefly, $35 \mu \mathrm{g}$ of denatured, unlabeled target DNA was loaded onto a filter membrane (BA-85; diameter, $23 \mathrm{~mm}$; Schleicher \& Schuell, Dassel, Germany) and the membrane was baked at $80^{\circ} \mathrm{C}$ for 3 h. The DNA for the probe was labeled with the Multiprime DNA-labeling system (Amersham, Amersham, United Kingdom) with $\left[\alpha^{-32} \mathrm{P}\right] \mathrm{dCTP}$, and the labeled DNA preparation was purified with a NICK column (Pharmacia LKB Biotechnology, Bromma, Sweden) and ethanol precipitation. The radioactivities of the DNA probes ranged from $10^{5}$ to $10^{6} \mathrm{cpm} / \mu \mathrm{g}$. After preincubation at $60^{\circ} \mathrm{C}$ for $5 \mathrm{~h}$, the unlabeled DNA on the membrane was hybridized with $20 \mathrm{ng}$ of denatured ${ }^{32} \mathrm{P}$-labeled DNA in $1 \mathrm{ml}$ of $6 \times \mathrm{SSC}$ containing $0.02 \%$ (wt/vol) bovine serum albumin (fraction V), $0.02 \%$ (wt/vol) polyvinyl pyrrolidone, $0.02 \%$ (wt/vol) Ficoll 400 , and $0.08 \%$ (wt/vol) SDS at $60^{\circ} \mathrm{C}$ for $18 \mathrm{~h}$ in a Hybri-Bag (Cosmo-Bio, Tokyo, Japan). After hybridization, the filter membrane was removed from the hybridization fluid and washed with $6 \times$ SSC (three times) and
$2 \times$ SSC (two times) and then dried. The amount of filter-fixed DNA was estimated by measuring the radioactivity of the hybridized DNA on the filter in a liquid scintillation counter in $10 \mathrm{ml}$ of toluene scintillant containing 33\% (vol/vol) Triton $\mathrm{X}-100,0.27 \%$ (wt/vol) 2,5-diphenyloxazole, and $0.007 \%$ (wt/ vol) 1,4-bis[2-(5-phenyloxazolyl)]benzene. Triplicate tests were run for each assay, and the results were normalized to $100 \%$ for the homologous DNA-DNA hybridization.

SDS-PAGE analysis. SDS-polyacrylamide gel electrophoresis (SDS-PAGE) was performed by the method of Laemmli (12), with the Micro Slab KS-8010 gel electrophoresis system (Marysol, Tokyo, Japan). Whole bacterial cells of each of the strains were heated in solubilizing buffer $(0.125 \mathrm{M}$ Tris buffer [pH 6.8] containing 4\% [wt/vol] SDS, $20 \%$ [vol/vol] glycerol, and $5 \%$ [vol $/ \mathrm{vol}] 2$-mercaptoethanol) for $10 \mathrm{~min}$ at $100^{\circ} \mathrm{C}$. After centrifugation at $10,000 \times g$ for $15 \mathrm{~min}$, the protein concentrations of the supernatants were determined by the protein assay kit (Bio-Rad Laboratories, Richmond, Calif.). The supernatant $(10 \mu \mathrm{g}$ of each) from each bacterial strain was applied to an SDS-polyacrylamide linear gradient (10 to 20\%) gel. Electrophoresis was conducted at a constant $20 \mathrm{~mA}$ at room temperature. After electrophoresis, the gel was stained with Coomassie brilliant blue R-250.

\section{RESULTS AND DISCUSSION}

In the present study, DNAs were isolated from the type strains of 10 species belonging to the genus Eubacterium and reference strains. All DNA preparations were considered sufficiently pure when the $A_{260} / A_{280}$ ratios were greater than 1.8. As listed in Table 1 , the $\mathrm{G}+\mathrm{C}$ contents of the DNAs from the Eubacterium species ranged widely, from 38 to $62 \mathrm{~mol} \%$, and the species were separated into three groups based on $\mathrm{G}+\mathrm{C}$ content. The groupings were $E$. aerofaciens, E. limosum, and $E$. timidum at nearly $50 \mathrm{~mol} \%$ (middle-content group); $E$. alactolyticum and $E$. lentum at roughly $60 \mathrm{~mol} \%$ (high-content group); and $E$. brachy, $E$. nodatum, $E$. rectale, $E$. saburreum, and $E$. yurii at almost $40 \mathrm{~mol} \%$ (low-content group). All of the species in the high- and low-content groups had $\mathrm{G}+\mathrm{C}$ contents significantly different (nearly $10 \%$ ) from that of $E$. limosum, which is the type species of the genus Eubacterium. These 
results indicated that of the 10 Eubacterium species investigated in this study, 7 species, including two subspecies, were likely to belong to genera separate from Eubacterium.

The $\mathrm{G}+\mathrm{C}$ contents of several Eubacterium species have been previously reported $(14,21)$, and all of these values were estimated by the thermal melting method. In the present study, $\mathrm{G}+\mathrm{C}$ contents were measured by the HPLC method. To confirm the validity of the method, DNA was extracted from Escherichia coli $\mathrm{K}-12$ and the $\mathrm{G}+\mathrm{C}$ content of the DNA (in moles percent) was preliminarily quantified by HPLC. The DNA of $E$. coli B (purchased from Funakoshi Chemicals, Tokyo, Japan) was also analyzed by this method. The $\mathrm{G}+\mathrm{C}$ contents of $E$. coli $\mathrm{K}-12$ and $\mathrm{B}$ were correctly determined to be 50.7 and $51.4 \mathrm{~mol} \%$, respectively. The $\mathrm{G}+\mathrm{C}$ contents of the DNAs of E. yurii subsp. yurii and E. yurii subsp. margaretiae and two strains of E. timidum corresponded to each other ( 40 and $50 \mathrm{~mol} \%$, respectively; Table 1 ). These results demonstrated that the HPLC method used in this study was valid for these determinations.

Quantitative DNA-DNA hybridization studies with the membrane filter technique (Table 1) showed that the labeled DNA probe from $E$. timidum ATCC 33092 was reasonably (91\%) homologous to the DNA of E. timidum ATCC 33093, which is the type strain of this species. Also, 60\% DNA reassociation was observed between $E$. yurii subsp. yurii and $E$. yurii subsp. margaretiae, which agreed with the results of Margaret and Krywolap $(13,14)$. These observations support the validity of the data on the species studied.

The reassociation percentages among the DNAs of the different Eubacterium species, as well as the DNAs of $A$. viscosus and $P$. nigrescens, which served as the out group for comparisons, were less than $20 \%$ in all cases and less than $10 \%$ in most cases. Even for Eubacterium species in the same $\mathrm{G}+\mathrm{C}$ content group, the levels of mutual DNA homology were very low values (Table 1 ).

Johnson (8) has proposed that groups of bacteria with intragroup DNA homology of 80 to $90 \%$ and intergroup homology between 60 and $70 \%$ could be considered different subspecies within a species. While there has been no general agreement regarding the phylogenetic definition of a genus (36), Johnson has also stated that the minimum DNA-DNA homology level among members of a genus should be $20 \%$ (9). These criteria, taken with the results of DNA-DNA hybridizations and estimations of $\mathrm{G}+\mathrm{C}$ content in the present study, suggest that some of Eubacterium species examined may need reassignment to different genera. A background of support for these findings is given by recent studies of $16 \mathrm{~S}$ rRNA sequences showing that $E$. biforme, E. limosum, $E$. tenue, and $E$. alactolyticum are grouped phylogenetically with distinct clusters of Clostridium and Acetobacterium species and that the genus Eubacterium may be incoherent $(26,37)$.

When SDS-soluble proteins were analyzed by SDS-PAGE analysis, it was shown that the protein profile patterns of these Eubacterium species were quite distinct from each other (Fig. 1). We were unable to detect major bands shared by all of the species examined in the present study. The different protein profiles of ultrasonic extracts from oral Eubacterium species, which were estimated by SDS-PAGE with a constant gel concentration ( $7.5 \%$ ), were reported previously (23). However, in the present study, whole bacterial cell extracts were used for SDS-PAGE with a gradient gel (10 to 20\%). That demonstrated clearly the great heterogeneity of structural proteins among these Eubacterium species.

Species of the genus Eubacterium are fundamentally different from the other anaerobic non-spore-forming, gram-positive rods, according to the major metabolic products. The

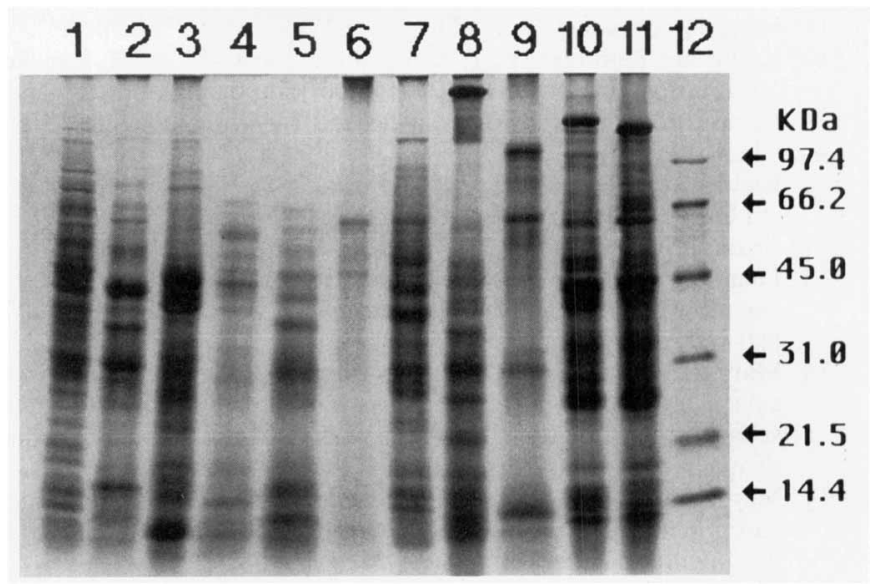

FIG. 1. SDS-PAGE (10 to $20 \%$ gradient) profiles of SDS-soluble proteins of bacterial cells from Eubacterium species. All samples were prepared as described in Materials and Methods. Lanes: 1, E. aerofaciens ATCC $25986^{\mathrm{T}} ; 2$, E. alactolyticum ATCC $23263^{\mathrm{T}} ; 3, E$. brachy ATCC $33089^{\mathrm{T}} ; 4$, E. lentum ATCC $25559^{\mathrm{T}} ; 5$, E. limosum ATCC $8486^{\mathrm{T}} ; 6, E$. nodatum ATCC $33099^{\mathrm{T}} ; 7$, E. rectale ATCC $33656^{\mathrm{T}} ; 8, E$. saburreum ATCC $33271^{\mathrm{T}}$; 9, E. timidum ATCC $33093^{\mathrm{T}} ; 10$, E. yurii subsp. yurii ATCC $43714^{\mathrm{T}}$; 11 , E. yurii subsp. margaretiae ATCC $43715^{\mathrm{T}} ; 12$, protein molecular size standards.

classification is based on assignment of species to the genus Eubacterium by a process of elimination from other anaerobic genera (21), which is likely to result in assembly of species which are phylogenetically distant from each other.

The present study demonstrates remarkable genetic heterogeneity among the 10 Eubacterium species studied. Although a more complete investigation is necessary before substantial taxonomic decision are made, these results may assist identification of these microorganisms and suggest a basis for reclassification of the genus Eubacterium.

\section{ACKNOWLEDGMENT}

This study was supported in part by grants-in-aid for scientific research from the Ministry of Education, Science and Culture of Japan (01771462, 04807130, 05807169, and 06044082).

\section{REFERENCES}

1. Ando, N., and E. Hoshino. 1990. Predominant obligate anaerobes invading the deep layers of root canal dentine. Int. Endod. J. 23: 20-27.

2. Edwardsson, S. 1974. Bacteriological studies on deep areas of carious dentine. Odontol. Revy 25(Supp. 32):1-143.

3. Hill, G. B., O. M. Ayers, and A. P. Kohan. 1987. Characteristics and sites of infection of Eubacterium nodatum, Eubacterium timidum, Eubacterium brachy, and other asaccharolytic eubacteria. J. Clin. Microbiol. 25:1540-1545.

4. Holdeman, L. V., E. P. Cato, J. A. Burmeister, and W. E. C. Moore. 1980. Descriptions of Eubacterium timidum sp. nov., Eubacterium brachy sp. nov., and Eubacterium nodatum sp. nov. isolated from human periodontitis. Int. J. Syst. Bacteriol. 30:163-169.

5. Hoshino, E. 1985. Predominant obligate anaerobes in human carious dentin. J. Dent. Res. 64:1195-1198.

6. Hoshino, E., N. Ando, M. Sato, and K. Kota. 1992. Bacterial invasion of non-exposed dental pulp. Int. Endod. J. 25:2-5.

7. Hoshino, E., N. Sato, F. Nakazawa, H. Uematsu, M. Sato, T. Ikeda, N. Kurihara, T. Sato, and M. M. Sato. 1992. Oral Eubacterium. Niigata Dent. J. 22:1-14.

8. Johnson, J. L. 1973. Use of nucleic acid homologies in the taxonomy of anaerobic bacteria. Int. J. Syst. Bacteriol. 23:308-315.

9. Johnson, J. L. 1984. Nucleic acid in bacterial classification, p. 8-11. In N. R. Krieg and J. G. Holt (ed.), Bergey's manual of systematic 
bacteriology, vol. 1. The Williams \& Wilkins Co., Baltimore.

10. Katayama-Fujimura, Y., Y. Komatsu, H. Kuraishi, and T. Kaneko. 1984. Estimation of DNA base composition by high-performance liquid chromatography of its nuclease P1 hydrolysate. Agric. Biol. Chem. 48:3169-3172.

11. Kondo, W., F. Nakazawa, M. Sato, and T. Ito. 1983. Structural studies of the antigenic polysaccharide of Eubacterium saburreum, strain T27. Carbohydr. Res. 117:125-131.

12. Laemmli, U. K. 1970 . Cleavage of structural proteins during the assembly of the head of bacteriophage T4. Nature (London) 277: 680-685.

13. Margaret, B. S., and G. N. Krywolap. 1986. Eubacterium yurii subsp. yurii sp. nov. and Eubacterium yurii subsp. margaretiae subsp. nov.: test tube brush bacteria from subgingival dental plaque. Int. J. Syst. Bacteriol. 36:145-149.

14. Margaret, B. S., and G. N. Krywolap. 1988. Eubacterium yurii subsp. schtitka subsp. nov.: test tube brush bacteria from subgingival dental plaque. Int. J. Syst. Bacteriol. 38:207-208.

15. Marmur, J. 1961. A procedure for the isolation of deoxyribonucleic acid from micro-organisms. J. Mol. Biol. 3:208-218.

16. Mashimo, P. A., Y. Murayama, H. Reynolds, C. Mouton, S. A. Ellison, and R. J. Genco. 1981. Eubacterium saburreum and Veillonella parvula. J. Periodontol. 52:374-379.

17. Meyer, S. A., and K. H. Scleifer. 1978. Deoxyribonucleic acid reassociation in the clasfication of coagulase positive staphylococci. Arch. Microbiol. 117:183-188.

18. Moore, W. E. C., L. V. Holdeman, E. P. Cato, R. M. Smibert, J. A. Burmeister, K. G. Palcanis, and R. R. Ranney, 1985. Comparative bacteriology of juvenile periodontitis. Infect. Immun. 48:507-519.

19. Moore, W. E. C., L. V. Holdeman, E. P. Cato, R. M. Smibert, J. A. Burmeister, and R. R. Ranney. 1983. Bacteriology of moderate (chronic) periodontitis in mature adult humans. Infect. Immun. 42:510-515.

20. Moore, W. E. C., L. V. Holdeman, R. M. Smibert, D. E. Hash, J. A. Burmeister, and R. R. Ranney. 1982. Bacteriology of severe periodontitis in young adult humans. Infect. Immun. 38:11371148.

21. Moore, W. E. C., and L. V. Holdeman Moore. 1986. Genus Eubacterium Prévot 1938, 294 AL , p. 1353-1373. In P. H. A. Sneath, N. S. Mair, M. E. Sharpe, and J. G. Holt (ed.), Bergey's manual of systematic bacteriology, vol. 2. The Williams \& Wilkins Co., Baltimore.

22. Nakazawa, F. 1985. Structural studies of the antigenic polysaccharide of Eubacterium saburreum, strain T17. Carbohydr. Res. 143: 185-190.

23. Nakazawa, F., and E. Hoshino. 1992. Immunochemical and structural characterization of the antigenic polysaccharide from Eubac- terium saburreum T18. Oral Microbiol. Immunol. 7:182-186.

24. Nakazawa, F., and E. Hoshino. 1993. Immunological specificity of oral Eubacterium species. J. Gen. Microbiol. 139:2635-2640.

25. Nakazawa, F., T. Ito, N. Sato, M. Sato, and E. Hoshino. 1987. Chemical composition and immunological characterization of polysaccharide antigen from Eubacterium saburreum T18. Infect. Immun. 55:871-876.

26. Olsen, G. J., C. R. Woese, and R. Overbeek. 1994. The winds of (evolutionary) change: breathing new life into microbiology. J. Bacteriol. 176:1-6.

27. Sato, T., E. Hoshino, H. Uematsu, and T. Noda. 1993. Predominant obligate anaerobes in necrotic pulps of human deciduous teeth. Microb. Ecol. Health Dis. 6:269-275.

28. Skaug, N., and T. Hofstad. 1983. Eubacterium saburreum L13 antigen containing a ketohexose as a main sugar constituent. Infect. Immun. 39:179-183.

29. Tanner, A. C. R., S. S. Socransky, and J. M. Gooson. 1984. Microbiota of periodontal pockets losing crestal alveola bone. J. Periodontal. Res. 19:279-291.

30. Theilade, E., O. Fejerskov, T. Karring, and J. Theilade. 1982. Predominant cultivable microflora of human dental fissure plaque. Infect. Immun. 36:977-982.

31. Uematsu, H., and E. Hoshino. 1992. Predominant obligate anaerobes in human periodontal pockets. J. Periodontal Res. 27:15-19.

32. Uematsu, H., F. Nakazawa, T. Ikeda, and E. Hoshino. 1993. Eubacterium saphenum sp. nov., isolated from human periodontal pockets. Int. J. Syst. Bacteriol. 43:302-304.

33. Wade, W. G., A. R. Gray, E. Absi, and G. R. Baker. 1991. Predominant cultivable flora in pericoronitis. Oral Microbiol. Immunol. 6:310-312.

34. Wade, W. G., J. Moran, J. R. Morgan, R. Newcombe, and M. Addy. 1992. The effects of antibacterial acrylic strips on the subgingival microflora in chronic periodontitis. J. Clin. Periodontol. 19:127134.

35. Wade, W. G., M. A. Slayne, and M. J. Aldred. 1990. Comparison of identification methods for oral asaccharolytic Eubacterium species. J. Med. Microbiol. 33:239-242.

36. Wayne, L. G., D. J. Brenner, R. R. Colwell, P. A. D. Grimont, O. Kandler, M. I. Krichevsky, L. H. Moore, W. E. C. Moore, R. G. E. Murray, E. Stackebrandt, M. P. Starr, and H. G. Trüper. 1987. Report of the Ad Hoc Committee on Reconciliation of Approaches to Bacterial Systematics. Int. J. Syst. Bacteriol. 37:463464.

37. Weizenegger, M., M. Neumann, E. Stackebrandt, N. Weiss, and W. Ludwig. 1992. Eubacterium alactolyticum phylogenetically groups with Eubacterium limosum, Acetobacterium woodii and Clostridium barkeri. Syst. Appl. Microbiol. 15:32-36. 